\title{
Stanisław Kosowski
}

\section{Kapłani współpracownicy biskupa w świetle soborowych uchwał}

Prawo Kanoniczne : kwartalnik prawno-historyczny 14/1-2, 75-86

1971

Artykuł został zdigitalizowany i opracowany do udostępnienia w internecie przez Muzeum Historii Polski w ramach prac podejmowanych na rzecz zapewnienia otwartego, powszechnego i trwałego dostępu do polskiego dorobku naukowego i kulturalnego. Artykuł jest umieszczony w kolekcji cyfrowej bazhum.muzhp.pl, gromadzącej zawartość polskich czasopism humanistycznych i społecznych.

Tekst jest udostępniony do wykorzystania w ramach dozwolonego użytku. 


\section{KAPLANI WSPÓEPRACOWNICY BISKUPA W SWIETLE SOBOROWXCH UCHWAL}

Treść: Wstęp. -- I. Glowa Kościoła partykularnego a Glowa Kościoła powszechnego, - II. Kapłani, podporząlkowani współpracownicy biskupa. - III. Zródlla wspólpracy i podporządkowania: a) Samo kapłaństwo, b) Parafia to , cząstka diecezji", c) Funkcje zlecone. - IV. Zewnętrzne przejawy podporządkøwanej wspólipracy: a) „Czynienie go obecnym w parafii", b) "Zespolenie woli", c) Posłuszenstwo, d) Część kapłana wobec biskupa. - Zakończenie.

\section{Wstep}

Sobór II Watykański wciąż trwa. Wprawdzie nie w formie zaplanowanych zebrań Ojców soboru, dyskusji nad schematami konstytucji, dekretów, deklaracji, lecz w formie wydobywania z uchwai soborowych: nauki, myśli, wskazań, zaleceń i przenoszenie ich w życie. To już jest w ścisłym znaczeniu Janowa ,Accomodata renovatio". "Accomodata renovatio" dotyczy, wedle pojęc soborowych: "Ecclesia ad intra" i „Ecclesia ad extra". Aspekt "ad intra" łący się ściśle $z$ aspektem ,ad extra'. Nie odłącza się od niego, raczej $w$ jakiś sposób wciąż rzutuje na niego. Chociaż temat mego artykułu mieści się $w$ aspekcie „Ecclesia ad intra" to jednak rzutuje w jakiś sposób na ,Ecclesiam ad extra", bo przecież dotyczy tych, którzy pracują nad Ludem Bożym. Treścią wejdzie więc ' W Janową ,accomodata renovatio".

\section{Głowa Kościola partykularnego a Glowa Kościola powszechnego}

Dekrety soborowe ukazują dowartościowanie biskupa. Mimo tego dowartościowania podkreślone jest dobitnie zwierzchnictwo nad nim Ojca św. W powolaniu biskupa mieści się troska o Kośció Chrystusowy, jednak jurysdykcyjnie jest głową Kościola partykularnego. To podkreśla konstytucja dogmatyczna o Kościele w siowach: „Poszczególni biskupi, stojący na czele Kościołów partykularnych sprawuja swe rządy pasterskie każdy nad powierzona sobie częścią Ludu Bożego, nie nad innym Knściołem ani nad ca- 
lym Kościołem powszechnym" 1. Jurysdykcja biskupia obejmuje tylko „część Ludu Bożego”, czyli jakiś Kościół lub Kościoły partykularne ściśle określone dekretem nominacyjnym. Tak ograniczona jurysdykcja ukazuje tym samym pewne podporządkowanie i zależność głowy Kościoła partykularnego od Głowy Kościoła powszechnego.

Tą zależność biskupa od papieża uwidoczniają również słowa: „Poszczególni biskupi, którym zlecono troskę o Kościół partykularny sprawują w imię Pana pieczę duszpasterską nad swymi owcami, pod zwierzchnictwem papieża, jako ich właściwi, zwyczajni, bezpośredni duszpasterze" 2. Znowu słowo „zwierzchnictwo" mówi o zależności biskupa od papieża.

To podporządkowanie, ta zależność biskupa od Głowy Kościoła powszechnego ukazuje konieczność jego współpracy $z$ nim mimo, że sam jest „właściwym, zwyczajnym i bezpośrednim” Pasterzem Kościoła partykularnego.

Tą konieczność wspomnianej współpracy biskupa z papieżem widać również z definicji diecezji, jaką daje dekret a pasterskich zadaniach biskupów w Kościele a mianowicie: „Diecezję stanowi część Ludu Bożego, powierzona pieczy pasterskiej biskupa i wspólpracujących $z$ nim kaplanów, tak by trwając przy swym pasterzu i zgromadzona przez niego w Duchu św. przez Ewangelię i Eucharystię tworzyła Kościół partykularny, w którym prawdziwie obecny jest i działa jeden, święty, katolicki i apostolski Kościół Chrystusowy" 3 . W Kościele partykularnym, jak widać z przytoczonej definicji diecezji, musi być i działać Kościół Chrystusowy. To zaś jest tylko wówczas możliwe, jeżeli biskup współpracuje z Ojcem św., a więc tworzy $z$ nim jedność. "Tej jedności usilnie strzec i bronić powinniśmy przede wszystkim my biskupi, którzy przewodniczymy $w$ Kościele, byśmy, wykazali, że i samo biskupstwo jedno jest i niepodzielne" 4, tak mówi św. Cyprian o współpracy i jedności biskupa z papieżem.

Dekrety soborowe ukazują więc stara prawdę, chociaż nowymi słowami, zależności i współpracy Pasterza Kościoła partykularnego z Pasterzem Kościoła powszechnego.

\section{Kapłani podporządkowani współpracownicy biskupa}

Biskupi wspólpracują z Ojcem św. Z biskupami winni znowu współpracować kapłani. Dekrety soborowe uważają kapłanów za

$1 \mathrm{KK} 28$

2 DB 11.

${ }^{3} \mathrm{j} . \mathrm{W}$.

4 Sw. Cyprian De unitate w tlum. ks dr J. Czuja — „Pisma i traktaty", Poznań 1937 s. 174. 
rzeczywistych współpracowników biskupa. Podkreślają to wyraźnie chociażby w takich zdaniach: „Wszyscy kapłani, zarówno diecezjalni jak i zakonni... stanowią grono skrzętnych współpracowników biskupiego stanu” 5 , lub ,bliższymi współpracownikami biskupa są kapłani, którym on powierza obowiązki duszpasterskie lub też dzieła apostolatu o charakterze ponadparafialnym" 6, czy wreszcie „ze szczególnego zaś względu współpracownikami biskupa sa proboszczowie..."7. W ,służbie braciom swoim" 8 kapłanj współpracują więc z biskupem. Tego chcą dekrety soborowe. Każde więc duszpasterstwo $\mathrm{w}$ diecezji winno byé skoordynowane z duszpasterstwem biskupa. Nie może istnieć na parafii jakieś duszpasterstwo calkiem samodzielne, oderwane od biskupa jak się to czasami zdarza w obecnych czasach. Winna więc istnieć współ- . praca kapłanów z biskupem.

Samo słowo w:spółpraca mieści w sobie znamię podporządkowania. Pojęcie współpracy suponuje jakiś naczelny autorytet ją regulujący. Mniejsza o to czy ten atatorytet regulowania $i$ kierowania posiada ktoś drogą: nominacji, wyboru lub uchwały. Ten autorytet jest jednak $w$ zespołowym działaniu i być musi by je odpowiednio ustawiać. Współprace trzeba więc ${ }_{ } \mathrm{W}$ danym zespole temu autory tetowi podporządkować.

W'slowach „współpracownicy biskupa” podkreślony jest wystarczająco jego kierowniczy autorytet odnośnie do duszpasterskiej działalności kapłanów. Oni z nim współpracują, czyli on koordynuje ich pracę podsuwając im swoje cele i zamierzenia duszpasterskie. Skoro tak to w perspektywie tej wspókpracy duszpasterskiej ukazuje się zwierzchnictwo biskupa nad kapłanami w ogóle a szczególnie nad kapłanami diecezjalnymi.

Zwierzchnictwo biskupa nad kapłanami oddanymi pracy dla dohra Ludu Bożego podkreślają wyraźnie dekréty ostatniego soboru. $\mathrm{W}$ tych dekretach jest uwidocznione całkiem wyraźnie zwierzchnictwo biskupa nad kapłanami współpracownikami $\mathrm{w}$ takich słowach: „Wszyscy prezbiterzy... szczególnie zaś w diecezji, której służbie są oddani pod zwierzchnictwem własnego biskupa" 9, lub „pod jego zwierzchnictwem" 10, albo „prezbiterzy... w wykonywaniu swej władzy zależni są od biskupów" 11. Biskup jest więc zwierzchnikiem kapłanów zatrudnionych przede wszystkim $\mathrm{w}$ duszpasterstwie.

$5 \mathrm{DB} 28$.

6 j.w.

7 j.w.

$8 \mathrm{KK} 18$.

9 DK. 8.

10 $\mathrm{KK} 30$,

11 j.w. 28. 
Kapłani są, wedle ustaw soborowych, współpracownikami biskupa ale jemu podporządkowanymi.

\section{III. Źródła współpracy i podporządkowania}

Współpraca $\mathrm{i}$ to podporządkowana kaptana $\mathrm{z}$ biskupem ma swoje podstawy, one właśnie ją tak ustawiają, że musi być taką a nie inną. O tym decyduje w pewnym stopniu:

a) Samo kapłaństwo. Konstytucja dogmatycyna o Kościele podkreśla takie, jak wyżej wspomniano, powiązanie prezbiterów z biskupami. To i takie powiązanie ma swój początek w samym kapłaństwie. W tej konstytucji czytamy: „Sobór Swięty uczy, że przez konsekrację biskupią udziela się pełni sakramentu kapłaństwa, która zarówno w tradycji liturgiczej Kościoła, jak i w wypowiedziach świętych Ojców nazywana jest najwyższym kapłaństwem, bądź pełnią świętego posługiwania” 12, oraz „Prezbiterzy, choć nie posiadają szczytu kapłaństwa i w wykonywaniu swej władzy zależni są od biskupów, związani są jednak z nimi godnością kapłańską i na mocy sakramentu kapłaństwa, na podobieństwo Chrystusa, najwyższego i wiekuistego Kapłana wyświęceni są, aby głosić Ewangelię, być pasterzami wiernych i sprawować kult Boży jako prawdziwi Kapłani Nowego Testamentu" 13. W samym kapłaństwie, wedle konstytucji, jest punkt oparcia dla konieczności wscólpracy i zależności prezbiterów od bisikupów. Jedni mają pełnię kapłaństwa, „widzimy, że Kościół uznaje biskupstwo jako pełnię kapłaństwa"14, a inni jej nie posiadają, czyli jedni uczestniczą w kapłaństwie Chrystusowym w pelnym a inni w mniejszym zasięgu. Jest więc nierówność w posiadaniu Kapłaństwa. Ta nierówność decyduje też o tym, że jedni mają większe' uprawnienia, przywileje, a tym samym większe obowiązki do wykonania niż drudzy.

Ta nierówność, wyżej ukazana, domaga się współpracy tych, którzy mają mniej z tymi, którzy więcej mają, gdyż ich potrzebują do zaspokojenia całości potrzeb Ludu Bożego. Tutaj w tej nierówności uczestnictwa w kapłaństwie Chrystusowym uwidocznia się teź, do pewnego stopnia, konieczność podporządkowania się słabiej wyposażonych w przywileje duchownych tym, którzy osiągnęli szczyt Kapłaństwa. Nierówność - mniejszy, większy - zmusza jednych do podporządkowania się drugim, a tym samym zmusza. jednych i drugich do wspólpracy $z$ soba w szerzeniu Królestwa Pożego na ziemi.

\footnotetext{
12 j.w. 21.

13 j.w. 28.

${ }_{14}$ Granat W. ks. - Dogmatyka katolicka, - Synteza, Lublin 1967 s. 468 .
} 
b) Parafia jest „cząstką diecezji”. Duszpasterstwo parafialne to wyraz podporządkowanej współpracy prezbiterów danej parafii z biskupem. „Parafia, wedle prawa kanonicznego, to oddzielna część terytorium diecezji z własnym kościołem, własną ludnością i własnym kapłanem, który $z$ urzędu swego sprawuje tamże duszpasterstwo" 15. Parafia to część terytorium diecezji z ludem na nim zamieszkałym. W tym ujęciu jest w niej coś martwego i żywego. Przez to terytorium parafia jest złączona $z$ diecezją.

Uchwały soborowe podają trochę inną definicję parafii. One nazywają parafię: „cząstką diecezji" I6, "lokalnym zgromadzeniem wiernych" 17, „lokalną wspólnotą" 18, „poszczególną wspólnotą wiernych" 19. Przytoczone określenia parafii ukazuja to co stanowi jej istote tj. Lud Boży, i lud zamieszkały na wyznaczonym i ściśle określonym jej terytorium. Ono właśnie określa i oznacza granice parafii. Wedle soborowego określenia terytorium schodzi na dalszy plan $w$ podanej definicji parafii. Lud wysuwa się na pierwszy plan i to zupełnie słusznie.

Określenie parafii, zarówno przez prawo kanoniczne jak i przez soborowe dekrety, ukazuje powiązanie parafii z diecezją. Parafia to „część terırtorium diecezji”, „cząstka diecezji”. Skoro zaś jest częścią, cząstką to jest $\mathrm{w}$ jakiśs sposób powiązana it uzależniona od diecezji. Nie jest od niej oderwana, przeciwnie jest $z$ nią mocno powiązana $\mathrm{i}$ to wewnętrznie i zewnętrznie. Diecezja wyciska skutkiem tego na niej swoje piętno i musi wyciskać, bo parafia wchodzi przeciez $w$ jej zasięg. $Z$ przytoczonych definicji parafii wynika więc konieczność współpracy podporządkowanej pasterza „cząstki diecezji" z Pasterzem calej diecezji.

Soborowe uchwały podają jeszcze, prócz definicji parafii, określenie duszpasterza cząstki diecezji tj. proboszcza. Ta definicja mówi, że proboszcz to „pasterz powierzonych mu'dusz w określonej cząstce diecezji pod zwierzchnictwem biskupa" 20. Choćby w tej definicji proboszcza nie było słów ,pod zwierzchnictwem biskupa', to w pozostałych, zwłaszcza ,pasterz dusz w określonej cząstce diecezji", ukazane jest podporządkowanie się proboszcza i tym samym wikariusza biskupowi. Podporządkowanie pociąga zaś za sobą współpracę. Księża pracujący na parafii mają więc współpracować ze swoim biskupem.

c) Funkcje zlecone. W dekrecie „O posłudze i życiu kapłańsłkim” czytamy takie zdanie: „Obowiązek posługi biskupiej został zleco-

15 B ączkow icz Fr. ks. Prawo kanoniczne, T. I. s. 456.

$16 \mathrm{DB} 30$.

17 KK 28.

18 j.W.

19 DK 5.

$20 \mathrm{DB} 30$. 
ny w stopniu podporządkowanym prezbiterom" 21. Te slowa można odnieść całkiem śmiało do każdego kapłana, który sprawuje w diecezji jakiś urząd kaścielny podyktowany potrzebami duszpasterskimi już nie parafii ale diecezji. Istnieją przecież $w$ każdej diecezji duszpasterstwa o charakterze ponadparafialnym np. męźów, niewiast, młodzieży, prawników, techników itp. W diecezji chełmińskiej istnieje urząd delegata biskupiego do komisariatów obejmujących swoim zasięgiem po kilka dekanatów. Diecezja chelmińska ma pięć takich komisariatów. Do obowiązków zaś tego delegata należy: ,wizytowanie dziekanów swego komisariatu raz na dwa lata, wprowadzenie $w$ urząd nowych dziekanów, przekazanie im aktów i pieczęci dekanalnej, oraz sporządzenie protokołu $z$ dokonanego aktu, jako też zatroszczenie się o godny pogrzeb zmarłych dziekanów. Do obowiązków delegata należą ponadto specjalne sprawy, powierzone mu przez Biskupa Ordynariusza" 22. Dekret „O pasterskich zadaniach biskupów w Kościele" wspomina też o wikariuszach biskupich, którym ten zleca potrzeby wiernych np. innego obrządku lub innego języka. Sam biskup rozpoznaje poirzebę utworzenia kościelnych urzędów diecezjalnych wyżej wymienionych czy jeszcze innych. On, a nie kto inny, zleca też jakiemuś kapłanowi wykonywanie tego urzędu.

Uchwały soborowe zaliczają księży, którym biskup zalecił dzieła apostolatu o charakterze ponad parafialnym, do bliższych współpracowników biskupa. W tych uchwałach czytamy: „bliższymi współpracownikami biskupa sa również i kapłani, którym on powierza obowiązki duszpasterskie lub też dzieła apostolatu o charakterze ponadparafialnym czy też odnośnie do wydzielonego terytorium diecezjalnego czy specjalnych grup wiernych, bądź też specyficznego rodzaju działalności" ${ }^{23}$. Księża pełniący wyżej wymienione czy podobne im urzędy kościelne są i winni być, jak chce sobór, „bliższymi wspólpracownikami biskupa". On przecież sam powierza im, wedle potrzeb diecezji, jakieś duszpasterskie zadanie do wykonania. Wypada więc, oraz zachodzi konieczność, by kapłan wypełniając takie polecenie biskupa współpracował ze swoim powiernikiem.

Dekrety soborowe ukazuja niektóre i wiele powodów skłaniających kapłanów do współpracy z biskupami w dziele bardzo zaszczytnym, jakim jest służenie ludowi Bożemu. One chca wyrobić przekonanie, że kapłani pracują na jakimś urzędzie kościelnym w diecezji w imieniu samego biskupa. Do niego bowiem należy duszpasterstwo w Kościele partykularnym. Biskup nie jest jednak.

$21 \mathrm{DK} 2$.

22 Statuty synodu diecezjalnego Chelmińskiego 1959 r. - Orędownik diecezji chełmińskiej 1959 Nr $9-10$ s. 316.

${ }^{23} \mathrm{DB} 29$. 
w stanie wypelnić osobiście owego, wielkiego, duszpasterskiego zadania o zasięgu diecezjalnym. Tym właśnie zadaniem a do pewnego stopnia i urzędem dzieli się z kapłanami, przeto całkiem słusznie powiada jeden $z$ dekretów soborowych: „Prezbiterzy... gromadzą w imieniu biskupa rodzinę Bożą... doprowadzają do Boga Ojca przez Chrystusa w Duchu Sw." 24. Kapłani spełniają więc rzeczywiście w imieniu biskupa duszpasterskie posługi dla wiernych. Współpraca w takich wypadkach nieunikniona, o ile świadomość odsłoni komuś czyli kapłanowi to wszystko, co kryje w sobie słowo „w imieniu biskupa”. W takim też ujęciu nabierają zrozumienia slowa jednego $z$ soborowych dekretów, że biskupi mają: „szczególną miłością otaczać kaplanów..., ponieważ oni w swoim zakresie podejmują ich zadania i troski"' 25 .

Wniosek $z$ tego ukazania dekretowych podstaw diecezjalnej współpracy jest całkiem prosty a mianowicie: zrozumienie przez kapłana swego zawodowego posłannictwa takim, jakim ono jest i jakim być powinno, prowadzi do wspólpracy $z$ bliższym czy dalszym przełożonym a zaś ta współpraca do miłości przełożonego wobec podwładnego.

\section{Zewnętrzne przejawy podporządkowanej wspólpracy}

Istnieje i powinna istnieć podporządkowana współpraca kapłanów z biskupem. Skoro istnieje to winno siez ujawniać na zewnątrz w jakiś sposób to, co kryje w sobie słowo „podporządkowany". Współpracujący z biskupem winien więc ukazywać na zewnątrz owego biskupa. To ukazywanie na zewnątrz biskupa przez kapłana z nim współpracującego dokonuje się przez:

a) Czynienie go obecnym w parafii. Konstytucja dogmatyczna - Kościele mówi, że kapłani „w poszczególnych lokalnych zgromadzeniach wiernych czynią oni obecnym w pewnym sensie samego biskupa" 26. Uzasadnienie tego, co mówi przytoczona konstytucja $w$ jymienionych słowach, mieści się w pewnym stopniu w rozdziale „Źródła współpracy i podporządkowania". Wszak kapłan' wykonuje zadania kościelne powierzone mu przez biskupa. Wykonuje więc jego zadania duszpasterskie. Przez wykonywanie tych zadań pomaga dany kapłan swemu biskupowi w jego duszpasterstwie. Przez to czyni biskupa obecnym w jakiś sposób w danej parafii, przy danym spełnianym przez siebie urzędzie kościelnym. Dany kapłan czyni to nieraz calkiem podświadomie. Nie myśli o tym, nie wie też o tym w momencie działania, że wyko-

\footnotetext{
DK 6.

DB 16.

26 KK 28.
} 
nując zlecone mu odgórnie zadanie „czyni obecnym w pewnym sensie samego biskupa".

Kapłan może jednak podejść całkiem świadomie do swego zadania, by uczynić biskupa obecnym: w kościele, w salce katechetycznej, na zebraniu, w parafii, przecież dany kapłan może ukazać od czasu do czasu tą rzeczywistość, że pelni tam zadanie biskupa, przez niego jest posłany, w jego imieniu duszpasterzuje $\mathrm{w}$ tej parafii. Wówczas wierni dojrzą za tym kapłanem i przy każdej jego działalności swego biskupa i powiążą się z nim duchowymi węzłami. Duszpasterz miejscowy przejmie też wtedy coś $z$ autorytetu swego przełożonego. Tak jest $i$ tak być powinno, bo zazwyczaj współpracujący ujawnia tego, $z$ którym współpracuje.

b) "Zespolenie woli". W omawianym zagadnieniu mamy do czynienia $\mathrm{z}$ wspólpracą niższego $\mathrm{z}$ wyższym, bo $\mathrm{w}$ naszym wypadku cieszącym się pełnią kapłaństwa Chrystusowego, a używając swieckiego określenia: pracownika z pracodawcą. Tak ujęta rzeczywistość zakłada pewną nierówność już to przy samym warsztacie pracy, już to na platformie stosunku tych dwóch osób do siebie. Istnieje więc pewna nierówność w samym ustawieniu tych dwóch osób obok siebie przy wspólnym warsztacie pracy. Tą warsztatową nierówność pomniejsza oraz niweluje zrozumienie zadania jakie ma ktoś wypełnić i roli jaka mu przypada przy tym wlaśnie zadaniu. Pomniejszenie i duża niwelacja różnicy personalnej może się zaś dokonać przez zespolenie woli ludzi z sobą współpracujących, w naszym wypadku: woli kapłana z wola biskupa.

$\mathrm{Na}$ takie właśnie zespolenie się dwóch woli, przy tym samym duszpasterskim warsztacie, zwraca uwage „Dekret o pasterskich zadaniach biskupów w Kościele” w słowach: „Współżycie między biskupami i kapłanami diecezjalnymi winno się opierać głównie na nadprzyrodzonych więzach milości, tak żeby zespolenie woli kapłanów z wolą biskupa uczyniło ich działalność duszpastersksa bardziej wydajną" 27. Sobór idzie w tym wypadku za wolą Chrystusa, Który chce, ,aby i oni, tj. kapłani, byli jedno w nas" 28 . Właśnie zrozumienie zadania jakie się ma wykonać i poświęcenie się dla niego potrafi ustawić dwie wole ludzkie, a raczej jedną obok drugiej ale tak, że obie chcą tego samego, w naszym wypadku, doprowadzenia ludzi powierzonych ich duszpasterskiej pieczy „do Boga Ojca przez Chrystusa w Duchu Św." 29.

W tym prowadzeniu ludzi do Boga ma głos decydujący ten, który pełni kierowniczą wladzę w Kościele partykularnym. Każdy kapłan, a zwłaszcza powołany, do wykonania jakiegoś kościelnego

27 DB 28.

28 Ewangelia św. Jana 17, 21.

$29 \mathrm{DK} 6$. 
zadania $w$ diecezji, musi się $z$ tym liczyć i przy jego spełnianiu dopasowywać swoją wolę do woli biskupa. Wówczas „Prezbiterium... jest związane $z$ biskupem jak struny $z$ cytrą" 30 , bo $w$ takim wypadku kapłan idzie wprawdzie obok biskupa, ale jednak razem $\mathrm{z}$ nim.

"Zespolenia woli" wymaga jedność działania a takie musi przecież byc duszpasterstwo w diecezji i w parafii.

c) Posłuszeństwo. Dobrze ustawiają się obok siebie wole współpracujących $z$ sobą osób, jeśli one chca tego samego. W takim wypadku żaden wysiłek $\mathrm{z}$ ich strony $\mathrm{w}$ ustawianiu się. One po prostu same się ustawiają. Gorzej jest już z ustawieniem woli dwojga czy więcej ludzi, jeśli one chcą wprawdzie tego samego, ale widzą różne drogi prowadzące do tego samego celu, lub chcą $\mathrm{w}$ danym wypadku coś przeciwnego, chociaż wciąż w zasięgu tych samych zadań. Uzgodnienie woli całkiem lub trochę przeciwnej pociąga za sobą ofiarę zainteresowanych osób, gdyż tutaj zachodzi konieczność jakiejś rezygnacji z częściowych czy całościowych swoich planów, zamiarów. Taka zaś rezygnacja pociąga za sobą pewne podporządkowanie się drugiej osobie, które nazywamy w potocznym języku posłuszeństwem.

Wiele jest takich okazji, które wymagaja od kapłana posłuszeństwa bisku:powi. Wystarczy wymienić: zwolnienie, przeniesienie, polecenie o charakterze: prawnym, administracyjnym, duszpasterskim, lub wreszcie zachęta, która też wyraża w jakiś sposób wolę danego przełożonego. W takich i $\mathrm{w}$ tym podobnych wypadkach kapłani winni okazywać biskupowi posłuszeństwo, które jest nie czym innym, jak tylko podporządkowaniem się woli przelożonego swojej, trochę przeciwnej lub całkiem odmiennej, woli. Podstawa do takiej rezygnacji nawet $z$ własnej woli na rzecz woli przelożonego mieści się $w$ należytym zrozumieniu ich urzędowej zależności od biskupa, oraz dobra sprawy sięgającego daleko poza ramy ich osobistej korzyści.

Sobór Watykański II każe księżom okazywać posłuszeństwo biskupom, czyli rezygnować w jakimś zakresie ze swej woli na rzecz ich woli, co czyni między innymi w talkich zdaniach: „kapłani powinni okazywać mu posłuszeństwo" 30, lub ,obowiązek posługi biskupiej został zlecony $\mathrm{w}$ stopniu podporządkowanym prezbiterom" 31 , albo "niech zatem zwiąże się ze swoim biskupem... posłuszeństwem" 32. Wedle przytoczonych słów, sobór żąda rzeczywiście posłuszeństwa kapłanów dla ich przełożonego, biskupa.

30 Bibliothek der Kirchväter eine Auswahl Patristischer Werke in Deutscher Übersetzung, Kempten - München, 1911, Ignatius Briefe 119.

$31 \mathrm{KK} 28$.

32 DK 2. 
$\mathrm{Na}$ posłuszeństwo kapłana wobec biskupa kładą też nacisk diecezjalne synody polskie. Oto wypowiedzi niektórych z nich: „Biskupom, jako prawowitym następcom Apostołów, należy się od duchowieństwa $i$ wiernych poszanowanie i posłuszeństwo" 33; "Arcybiskupowi Warszawskiemu oraz jego biskupom pomocniczym, jako prawowitym następcom Apostołów i pasterzom Kościoła, duchowieństwo diecezjalne i zakonne będzie okazywać należne poszanowanie, posłuszeństwo i wierność..." 34.

Prócz zaleceń posłuszeństwa, jak widać $z$ przytoczonych cytatów, statuty diecezjalne nakazują jeszcze wychowywanie w posłuszeństwie młodszego duchowieństwa przez starsze. To zalecenie ma nastẹpującą formę: „Starsi księża niech pouczają młodszych, że wolę przełożonego należy zawsze uszanować i spełnić" 35. Kościól w Polsce żąda posłuszeństwa niższego duchowieństwo wobec wyższego.

Zbierając to wszystko o podporządkowaniu jednej woli drugiej, trzeba powiedzieć, że dużo wcześniej ad Soboru Watykańskiego II i wspomnianych diecezjalnych synodów polskich, bo od czasu, w którym Chrystus już wypowiedział słowa: „Idąc na cały świat głoście ewangelię wszelkiemu stworzeniu" 36, dobro sprawy doprowadzenia rodziny Bożej od Boga Ojca wymaga właśnie posłuszeństwa podwładnych duchownych ich duchownym przełożonym.

d) Cześć kapłana wobec biskupa. Kapłan współpracując ze swoim biskuxpem $\mathrm{w}$ formie podporządkowanej darzy go, prócz posłuszeństwa, jeszcze należnym szacunkiem i czcią. Sw. Dionizy pisze w tej sprawie: „Prezbiterzy winni sprawiać biskupowi szczególną radość" 37. Szacunek i cześć okazywana biskupowi jest też jednym z wielu powodów wywołujących u niego radość, zadowolenie. To tė̇ każdy diecezjalny synod polski przypomina kapłanom obowiązek czci i szacunku wobec biskupów, jako prawowitych następców Apostołów. Te synody przypominają wspomniany obowiązek takimi i im podobnymi słowami: „Władzy duchownej, na wszystkich stopniach hierarchicznych, należy się ze strony kapłana szacunek i posłuszeństwo" 38, lub "cały kler diecezji winien być mu posłuszny..., otaczać go czcią i miłością" 39 .

Na szacunek i cześć należną biskupowi zwraca tė̇ uwagę Sobór Watykański II. Ojcowie tego soboru domagają się, jak widać z po-

\footnotetext{
33 j.w.

34 Synod diecezji przemyskiej 1955, stat. $35 \S 1$.

35 Drugi synod archidiecezji warszawskiej 1963, stat. 35.

36 Statuty synodu diecezjalnego chełmińskiego 1959, stat. 16.

37 Bibliothek... Apostelväter 135.

38 j.w.

39 Statuty synodu archidiecezji gnieźnieńskiej. Tytuł I - Duchowieństwo w ogólności - Rozdz. IV, 31 § 2.
} 
przednich rozdziałów, podporządkowania się kapłana biskupowi, jako swemu przełożonemu, jednak nie koniecznie z’musu, lecz raczej ze zrozumienia tej powinności, podyktowanego dobrem sprawy, jakiej się poświęca. Przy zrozumieniu nie ma miejsca na jakąś niechęć do biskupa, która jest zawsze czymś ujemnym u człowieka, a tymbardziej musi być taką u duchownej osoby. Wola biskupa, konieczność posłuszeństwa, zrobienie uwagi nie mogą tworzyć u danego kapłana podstaw do powstania niechęci, nieuszanowania tego, który jest jego przełożonym ubogaconym pełnią kapłaństwa. Sobór przypomina kapłanom, by posłuszeństwo względem biskupa łączyli z czcią jemu od nich należną. Czytamy bowiem w konstytucji dogmatycznej o Kościele: „Kapłan powinien... ze czcią okazywać mu posłuszeństwo" 40 . W tym zdaniu sobór połączył cześć $z$ posłuszeństwem u tej samej osoby, w naszym wypadku, u kapłana wobec biskupa. Podobną myśl wyraża sobór w ,Dekrecie o posłudze i życiu kapłanów” w zdaniu: „Prezbiterzy... niech czczą $w$ nich władzę Chrystusa, najwyższego Pasterza" 41 . W przytoczonych znowi słowach sobór przypomina kapłanom powinność darzenia czcią biskupów, jako swoich przełożonych, ale bardzo zaszczytnych, bo posiadających władzę samego Chrystusa.

Przytoczone słowa Soboru można potrakitować jako przypomnienie o czci należnej biskupowi ze strony kapłanów. To przypomnienie nie jest jednak dla wszystkich kapłanów konieczne lub nie $\mathrm{w}$ jednakowych rozmiarach. Wszak wielu $\mathrm{z}$ nich ma dobre rozpoznanie swego służbowego stosunku wobec biskupa i nawet bez zaleceń, przypomnień, czy nakazów prawnych potrafi go słuchać i darzyć należną czcią.

\section{Zakończenie}

Ŝw. Ignacy pisze w jednym ze swoich listów: „Kto beż biskupa, bez kapłana i diakona coś czyni, ten nie jest czysty $w$ swoim sumieniu" 42. Te słowa skierowal św. Ignacy do laikatu. Można je też zastosować do osób duchownych i powiedzieć: „Kapłan, który bez biskupa, lub wbrew jego woli coś czyni nie jest czystym w swoim sumieniu". Rzeczywiście nie jest, gdyż w takim wypadku narusza swoją służbową zależność i obowiązek współpracy. Dany urząd kościelny i płynący z niego obowiązek został kapłanowi oddany, powierzony. Oddanie i powierzenie kryje w sobie myśl zastępstwa, a więc urząd kościelny w diecezji pełni się zawsze w imieniu i za-

\footnotetext{
40 I synod diecezji częstochowskiej 1954, stat. 50.

${ }^{41} \mathrm{KK} 28$.

$42 \mathrm{DK} 7$.
} 
stępstwie biskupa. Zastępstwo jako takie mieści w sobie obowiązek podporządkowanej współpracy, w naszym wypadku kapłana $\mathrm{z}$ biskupem.

\section{ZUSAMIMENFASSUNG}

\section{Die Priester, die Mitarbeiter des Bischofs nach des Konzils Beschliussen}

Das vatikanische Konzil dauert immer. Sein fortwährendes Wirken wird in der Realisierung der Beschlüsse im Leben der Kirche bemerkt, das ist sogenante ,accomodiata renovatio".

Die Dekrete des Konzils haben einerseites den Bischof sehr hochgeschätz, anderseits die Oberherrschaft des Papstes über ihn gezeigt. Mit dem Beruf des Bischofs wird zwar die Sorge für die ganze Christliche Kirche verbunden, jedoch auf dem Gebiet der Jurisdiktion ist er das Haput nur der partikularen Kirche. Diese beschränkte Jurisdiktion zeigt seine Unterordnung und Abhängikeit von dem Haupt der allgemeinen Kirche und zugleich die Notwendigkeit der Mitarbeit.

So der Bischof mit dem Papst wie der Priester mit dem Bischof soll arbeiten. Die Mitarbeit des Priesters muss dem Bischof untergeordnet sein. Die Dekrete des Konzils sagen: ,unter der Oberherrschaft des Bischofs".

Das Fundament dieser unterordnenden Mitabeit bildet dasselbe Priestertum des Bischofs und des Priesters. Der Enste hat die Vollheit des Priestertums, der Zweite besitz sie nicht, darum ist der Zweite von dem Ersten abhängig.

Die Pfarrgemeide ist ein Teilchen der Diozese, in engem Zusammenhang damit steht die Pflicht der Zusammenarbeit und Subordination.

Endlich die Arbeit mit ganzer Reichweite über die Pfarrgeneinde, die dem Priester von dem Bischof beauftragt wird, zwingt ihn zur Mitarbeit.

Jeder Priester erfüllt die kirchliche Pflicht in der Pfarrgemeinde im Namen des Bischofs, und dadurch zeigt er seine Mitarbeit. Der Preister macht den Bischof nuter den Gläubigen bemerktbar, da er von Zeit zu Zeit sagt, er sei vom Bischof geschiekt und in seinem Namen seelsorgt.

Der Priester leistet dem Bischof immer Gehorsam.

Bei der Erfüllung der kirchlichen Pflicht soll der Priester dasselbe wollen was der Bischof will. Der Wille des Priesters ist mit dem Willen des Bischofs vereinigt. Den Willen des Bischofs erfüllt er selbst wenn dieser Willen seinen eigenen Willen entgegengesetzt sei.

Erzeigt ihm immer die Achtung und Ehre. Das vatikanische Konzil erinnert die Priester daran, dass sie immer den Gehorsam mit der Ehre verbinden sollen.

Jeder Priester arbeitet in der Pfarrgemeinde im Namen und in der Vertretung des Bischofs. Die Vertretung ist mit der subordinierender Mitarbeit verbunden. Als Vertreter des Bischofs muss also der Priester in der Seelsorge immer den guten Willen der engen Mitarbeit vorzeigen.

43 Bibliothek... Apostelväter, Ignatius an die Trallianer 134. 